\title{
Grass-Fed: Nature's Intention
}

\section{According to recent studies, grass-fed animals produce leaner, healthier beef.}

\author{
By Dawn Rahn
}

Think back to several centuries ago when Native Americans lived in harmony with nature. Fast forward to the $21^{\text {st }}$ century where there is a trend in America to go back to nature. Many farmers and ranchers are returning animals to the open pasture, and in return are eating healthier meat products and employing natural range management practices.

Traditional producers have a meat product that is higher in more of the bad fat that clogs our arteries and less of the good fat essential for better health. Often times the dietitians for people with a diet high in saturated fats say eat less red meat. But new research suggests eating less grain-fed meat and eating grass-fed meat, which is leaner, actually lowers cholesterol levels.

Along with leaner meat, grass-fed animals have a higher amount of a type of good fat called "Omega-3 fatty acids." Omega-3 fatty acids are not only good for your health but they are essential for normal growth and development. Grass-fed meat has from two to six times more Omega-3s than grain-fed meat.

Omega-3 fatty acids are not only beneficial to your health, but they also help in normal growth and development. These acids cannot be manufactured in your body, so they must be received from your diet. Omega-3 fatty acids contain many disease-fighting contents. The brain is largely made up of fats, and Omega-3 fatty acids make up the most important part of those fats.

If you receive a proper amount of these fatty acids in your diet, it has been found that the risk of having mental disorders, aggressive behavior, or attention-deficit disorder can be lowered. People with diets high in Omega-3s are also less likely to have high blood pressure, heart attacks, or cancer.

Unfortunately, the American diet is sufficiently low on Omega-3s. Only $40 \%$ of Americans consume adequate levels, and $20 \%$ have levels so low they can barely be detected. The reason for the decline in Omega-3s in grain-fed animals is that Omega-3s are formed in the green leaves of plants. When animals are taken off grass and fed grain, they gradually lose their storage of these fatty acids. For this reason, grass-fed animals are in high demand from the consumer.

\section{Bison Also Good Source Of Omega-3s}

Bison, an animal group once considered on the brink of extinction, is one group of animals that appear to be at home on the range. They are making an increase in population due to consumer demand for their meat. By the late 1800 's, bison were nearly extinct. Through the help of conservationists and ranchers who know the value of bison, they have begun to increase in number.

The Perfect 10 Ranch located south of Rose, Nebraska raises grass-fed bison. The ranch currently has 50 pasture subdivisions. The meadows are used heavily in the summer, and the warm-season Sandhills native grass is usually saved and used for winter

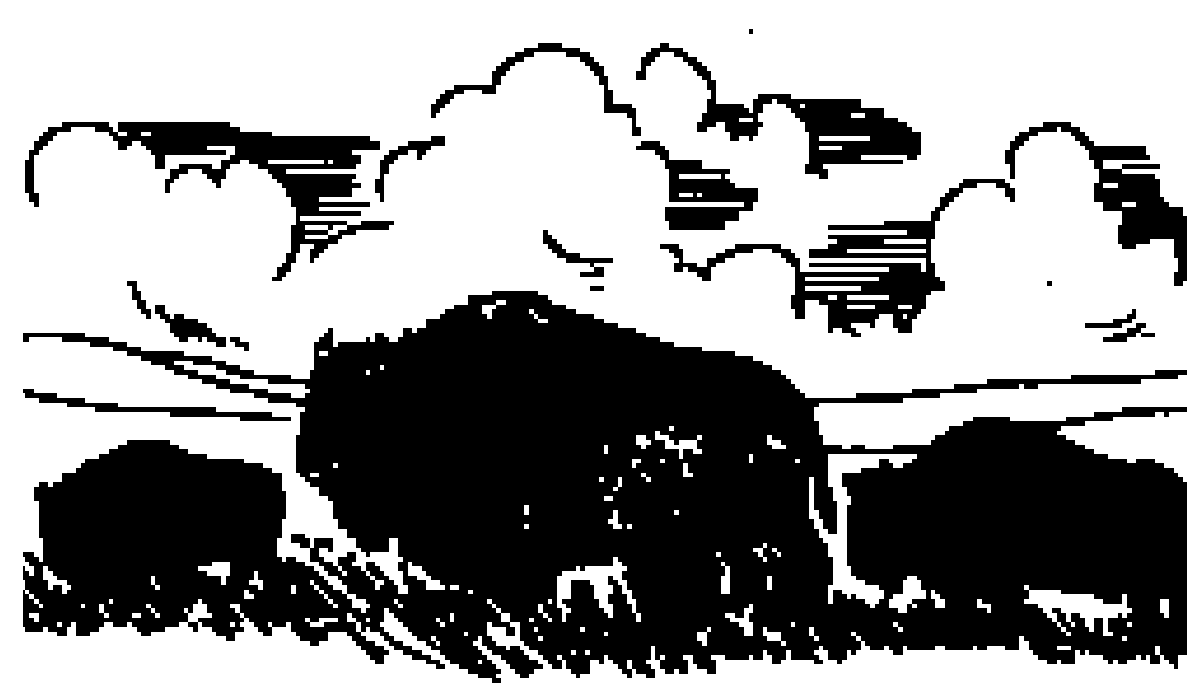


grazing. With this grazing program, the owner of the ranch has found that his warm season grasses have grown back in larger amounts with the plants having stronger root systems. Among these are grasses such as Big Bluestem, Indiangrass, and Switchgrass. The operator likes to use a herd size of around 900 animals, which are moved about every three days during the grassgrowing season.

Bison are higher in protein than beef, but lower in fat, cholesterol, and calories. However, many of these animals are being taken off grass and put on feedlots where they are losing their essential Omega-3 fatty acids. Bison are very efficient grazers, so feeding them grain makes little sense. The grazing bison will lose weight during the winter months, but when spring comes, they can rebound quickly and regain their weight. They are not such efficient grain consumers, so all grain does is make their amount of bad fats higher, and lower the overall meat quality. In some cases, grain-fed animals also have higher amounts of Ecoli, which can be dangerous to the consumer's health.

Another reason grass-fed bison are healthier for the land and consumer is the fact that they are survivors. It has been found that fewer bison die during extreme cold or hot weather than other grain-fed animals because of their naturalness. Bison are also the only mammal that has never had cancer. They are roamers and move about every three days.

With their movement, they help improve the land by churning the soil with their sharp, split hooves. This allows new plant growth and a healthier root system. If a pasture has a healthier root system, it is better able to contain water. The bison work their own urine and manure back into the soil, fertilizing and speeding the decomposition process naturally in about ten days. These animals also break up frozen soil in the spring, allowing water to percolate into the soil. When they shed their shaggy winter coats by rolling on the ground, autumn seeds

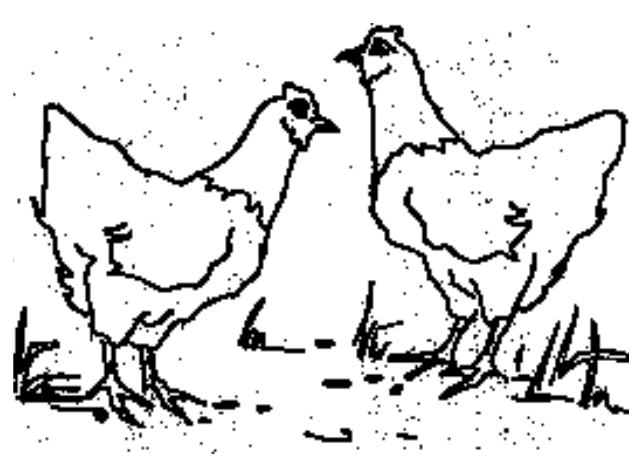

Omega-3s. In addition to being healthier grass-fed poultry is appealing to the taste buds.

Grass-fed animals appear to have advantages over grain-fed animals. The main advantages include the health benefits of the Omega-3s, and range management practices that allow better plant growth and efficient use of range land. Although grassfeeding animals, is only one alternative to a healthier animal product, many people are recognizing grassfarmers as excellent caretakers of our environment.

caught in their hair are redeposited, resulting in native grasses growing anew. Bison also eat dead grass, thus reducing fire hazards and allowing easier photosynthesis for new grass. Uneven land is leveled by bison, since they break down bumps and kick up clots in pasture ruts.

\section{Poultry Can Be Grass-Fed}

Along with grass-fed bison and cattle, poultry can also be grass-fed. However, unlike ruminant animals, poultry cannot survive on grass alone. They need forms of high quality protein, such as insects, grains, or legumes. Chickens that are raised on pasture will get as much as $30 \%$ of their calories from grass, clover and other greens.

Poultry traditionally are vaccinated, medicated, and exposed to artificial lighting. A recent study showed that after vaccination or medication is out of a chicken's blood, it could show up in the eggs. With grass-fed management practices chickens do not have this problem, because they are not vaccinated or medicated.

Another issue again is the Omega$3 \mathrm{~s}$. Unless given the chance to eat greens where Omega-3s are most abundantly found, the eggs laid by these animals had a 20-1 ratio of 20 eggs with sufficient Omega- 3 s to 1 eggs with sufficient Omega-3s. In other studies it has been discovered that grass- fed chicken meat is healthier than conventionally raised chickens. The free-range chickens were lower in fat and calorie percentages, yet were higher in vitamin $\mathrm{A}$ and
This was the second place paper for the High School Youth Forum presentation competition at the SRM Annual meeting in 2001 in Kona, Hawaii.

Dawn Rahn can be contacted at HC 68 Box 7, Atkinson, Nebraska 68713, Phone: 402-925-2609.

\section{References}

Nation, Allen, "Large and Small Herd Buffalo Ranchers Find Grassfed Meat to be a Lucrative Enterprise", The Stockman Grass Farmer July, 1999. Vol.56, \#7

Robinson, Jo, Why Grass fed is Best. Vashon, Washington,: Vashon Island Press, 2000.

Schulte, Erin, "Survival of the Fittest: A Beastly Will to Survive", Back From Oblivion, Depth Report 28, October, 1997, College of Journalism and Mass Communications, University of Nebraska at Lincoln.

Interview with Dave Hutchinson, Perfect "10" Buffalo Ranch, HC 75, Box 146, Rose, Nebraska, August 8, 2000.

Interview with Chuck and Bev Henkel, Tucker Hill Farm. 1614 N. 61 ${ }^{\text {st }}$, Norfolk. Nebraska, August 6, 2000. 